\title{
Moral marketplaces: regulating the food markets of late Elizabethan and early Stuart London
}

\author{
Charlie Taverner* ${ }^{\star \dagger}$ (iD) \\ Institute of Historical Research, University of London, Senate House, Malet Street, London, WC1E 7HU, \\ UK \\ ${ }^{\star}$ Corresponding author. Email: charlie.taverner@sas.ac.uk
}

\begin{abstract}
This article examines the economic culture of urban food markets in early modern England. It focuses on London between 1590 and 1640 to argue that market regulation, even in fast-growing, commercializing cities, was underpinned by moralized values. It also assesses a largely untapped citywide book of fines, containing payments for regulatory offences. The first section outlines London's market system and regulation, the second looks at enforcement in practice and the third discusses the underlying values. This contributes to our understanding of day-to-day food marketing and proposes that studies of 'moral economy' should examine everyday commerce and major cities.
\end{abstract}

In February 1615, London's chamberlain recorded a payment from a 'Comon Huxster', Sara Goodwyn, fined $2 s$ for buying three flitches of bacon in Leadenhall market, which she planned to sell again in Southwark. ${ }^{1}$ Goodwyn was one of several dozen men and women, over the previous two years, fined for breaking the rules of the City's markets. Those long-standing rules were concerned, above all, with protecting the integrity of the marketplace. Ideally, country producers arriving with supplies were supposed to sell direct to citizen shoppers in these sanctioned spaces. This system was rooted in custom and justified as beneficial for the commonwealth. Even in bustling, commercial London, urban governors regulated food marketing within this moralized framework.

For almost 50 years, E.P. Thompson's concept of the 'moral economy' has been the dominant paradigm for understanding the economic culture of early modern England. The actions of eighteenth-century grain rioters, Thompson argued, were legitimated by a 'consistent traditional view of social norms and obligations,

\footnotetext{
${ }^{\dagger}$ While working on this article, I was supported by a doctoral scholarship at Birkbeck, University of London, and the Economic History Society Anniversary junior research fellowship. I thank Vanessa Harding and Brodie Waddell for commenting on early drafts, Izzy Fraser for careful editing, and the journal's reviewers for their encouraging suggestions.

${ }^{1}$ London Metropolitan Archives (LMA), Book of Fines, for Breach of City Ordinances, COL/CHD/CM/ 10/001 (hereafter Fines Book), fol. 255r.

(c) The Author(s), 2020. Published by Cambridge University Press
} 
of the proper economic functions of several parties within the community'. ${ }^{2}$ Since Thompson's publication, the notion of a moral economy has influenced work on economic culture at times of relative calm, as well as crisis, and in urban settings, as well as the countryside. In the last 20 years, historians have described a complex body of ethics, based on religious, civic, and communitarian values, which textured early modern economic relations. This began with Craig Muldrew's description of social and ethical ideas of credit, which shaped dealings in the marketplace, instead of pure self-interest. ${ }^{3}$ We have learnt since that 'moral economies' were diverse and multiple, and economies across Europe were embedded with social issues. ${ }^{4}$ These values co-existed with a broader process of commercialization. ${ }^{5}$ James Davis has argued for the existence of a 'pragmatic moral economy' in the marketplaces of medieval England, at a time when low-level policing was difficult and asymmetries of information between buyers and sellers were common. ${ }^{6}$

Davis' work is unusual for considering market ethics during day-to-day dealings. As the complexity of our understanding of economic culture has grown, the historiography has become less focused on small-scale transactions in marketplaces. Older, empirical works still provide the fullest description of how early modern people bought and sold food. ${ }^{7}$ The limited number of works on London's food supply have concentrated on institutions and flows of trade. ${ }^{8}$ The practice of buying and selling in the market is only now starting to gain attention, due to recognition of women's importance to retail. ${ }^{9}$ This lack of focus on the circumstances where

\footnotetext{
${ }^{2}$ E.P. Thompson, 'The moral economy of the English crowd in the eighteenth century', Past \& Present, 50 (1971), 76-136, at 79. For a summary of literature that followed Thompson, see J. Bohstedt, The Politics of Provisions: Food Riots, Moral Economy, and Market Transition in England, c. 1550-1850 (Farnham, 2010).

${ }^{3}$ C. Muldrew, The Economy of Obligation: The Culture of Credit and Social Relations in Early Modern England (Basingstoke, 1998), 2-3.

${ }^{4}$ B. Waddell, God, Duty and Community in English Economic Life, 1660-1720 (Woodbridge, 2012), 228; L. Fontaine, The Moral Economy: Poverty, Credit, and Trust in Early Modern Europe (Cambridge, 2014), pp. 2-3.

${ }^{5}$ D. Pennington, Going to Market: Women, Trade and Social Relations in Early Modern English Towns, c. 1550-1650 (Farnham, 2015), 166; A.T. Brown, 'A money economy? Provisioning Durham cathedral across the dissolution, 1350-1600', in J.P. Bowen and A.T. Brown (eds.), Custom and Commercialisation in English Rural Society: Revisiting Tawney and Postan (Hatfield, 2016), 181-202, at 201.

${ }^{6}$ J. Davis, Medieval Market Morality: Life, Law and Ethics in the English Marketplace, 1200-1500 (Cambridge, 2012), 450-7; J. Davis, 'Baking for the common good: a reassessment of the assize of bread in medieval England', Economic History Review, 57 (2004), 465-502, at 493-4.

${ }^{7}$ A. Everitt, 'The marketing of agricultural produce', in J. Thirsk (ed.), The Agrarian History of England and Wales, vol. IV: 1500-1640 (Cambridge, 1967), 466-592; J. Chartres, Internal Trade in England 15001700 (London, 1977); J. Chartres, 'Food consumption and internal trade', in A.L. Beier and R. Finlay (eds.), London 1500-1700: The Making of the Metropolis (London, 1986), 168-96.

${ }^{8}$ Colin Smith, 'The wholesale and retail markets of London, 1660-1840', Economic History Review, 55 (2002), 31-50; P.V. McGrath, 'The marketing of food, fodder and livestock in the London area in the seventeenth century, with some reference to the sources of supply', University of London MA thesis, 1948; F.J. Fisher, 'The development of the London food market', Economic History Review, 5 (1935), 46-64. For an exception, see M. Dorey, 'Controlling corruption: regulating meat consumption as a preventative to plague in seventeenth-century London', Urban History, 36 (2009), 24-41.

${ }^{9}$ E. Hubbard, City Women: Money, Sex and the Social Order in Early Modern London (Oxford, 2012); T. Reinke-Williams, Women, Work and Sociability in Early Modern London (Basingstoke, 2014); Pennington, Going to Market.
} 
these exchanges took place poses a challenge for understanding the moral economy. As Thompson warned when revisiting his original article, the concept of the moral economy had been conceived for a specific context and, if it was to be applied elsewhere, those norms and obligations had to be set out afresh. ${ }^{10}$

This article makes the case that the buying and selling of food in the markets of early modern cities were underpinned by a sense of morality. Values such as common good, just price and custom were invoked not only during the charged moments of rural grain riots, but in how urban food markets were ordered and regulated on an everyday basis.

To make this argument, I focus on a specific location, the urban marketplace, the main site of food selling in this period. For Fiona Williamson, the market was the exemplar of complex urban space, 'perhaps uniquely, a chimera, a place of shifting, unstable identities, claimed exclusively by none yet appropriated by many'. Women worked in the market, but men supposedly dominated the realm of business; it was a symbolic venue for civic events, but also a flashpoint for unrest; traders competed freely, but the market also stood for privilege and economic power; it was the community's main gathering spot, but also a site of social conflict. ${ }^{11}$ This article connects this sophisticated understanding of space to issues of economic culture, which allows us to consider how marketplaces were used and regulated. The urban moral economy relied on a certain conception of how traders should use the market's space.

In the three sections of this article, I examine the market system, the rules and their enforcement, and the underlying values in one particular setting: late Elizabethan and early Stuart London, between about 1590 and 1640. This snapshot of the English capital shows different forces in tension. London's population growth outstripped the rest of the country, more than trebling from 120,000 in 1550 to 375,000 in $1650 .{ }^{12}$ This growth put pressure on the food supply and the management of urban space. The system of street markets came under stress, before the fire of 1666 and subsequent rebuilding led to a dramatic reorganization. ${ }^{13}$ In the late sixteenth and early seventeenth centuries, London's rulers were in a bind. They needed to supply Londoners of all degrees with affordable food, to appease companies that wanted to protect their privileges, and to preserve a marketing system in which country traders brought their wares to the metropolis. For the study of early modern moral economy, a subject that has mostly centred on protests in small towns and the countryside, metropolitan London may appear a strange choice. Its size, commercial orientation and reliance on a vast hinterland for its food supply also made the capital untypical. Yet London offers a useful perspective.

\footnotetext{
${ }^{10}$ E.P. Thompson, Customs in Common (London, 1991), 338-40.

${ }^{11}$ F. Williamson, Social Relations and Urban Space: Norwich, 1600-1700 (Woodbridge, 2014), 203. On gender in the marketplace, see A. Flather, Gender and Space in Early Modern England (Woodbridge, 2007), 121-33. On conflict and power, see D. Postles, "The market place as space in early modern England', Social History, 29 (2004), 41-58.

${ }^{12}$ R. Finlay and B. Shearer, 'Population growth and suburban expansion', in Beier and Finlay (eds.), London 1500-1700, 37-57, at 48; V. Harding, 'The population of London, 1550-1700: a review of the published evidence', London Journal, 15 (1990), 111-28.

${ }^{13} \mathrm{C}$. Smith, 'The market place and the market's place in London, c. 1660-1840', University College London Ph.D. thesis, 1999, 38.
} 
Because of its scale and complexity, the management of markets presented problems, such as competing uses of space, opportunities for evasion and the sheer volume of business, which may have been less acute elsewhere. Despite such hurdles, the capital's governors fought to govern the food markets in line with a sense of the common good.

This is evident from the records of how the corporation regulated the several marketplaces within its jurisdiction. The article draws extensively on the deliberations and orders of the City's governing bodies, the court of common council and the court of aldermen. Because their interventions were occasional, to appreciate how market rules were enforced on a regular basis I have also examined a largely untapped source, the chamberlain's book of fines. ${ }^{14}$ This is an account of fines paid to the corporation for various infractions, from vending textiles of insufficient material to fishing at improper times. A significant proportion were paid for breaking marketplace rules, such as selling at illegal venues or, like the huckster Sara Goodwyn, buying in one market to offload in another, a crime known as regrating. I have analysed the marketing offences recorded in the book of fines over 39 years, from 1590 until the book's conclusion in 1628. The book offers a rare insight into ongoing market regulation across London and how that regulation sat beside other aspects of City government.

\section{Placing London's food markets}

Since the medieval period, the core principle of economic morality in food marketing had been the preservation of the 'open and public market': a dedicated place that guaranteed honest dealing by keeping all transactions visible. ${ }^{15}$ Meeting that goal was straightforward in a typical pre-industrial town. Across England and Wales, the 800 or so small market towns were the customary places for country people to sell surpluses and buy what they did not produce themselves. In these towns, the marketplace took different forms, most often a long street, or a triangle or square formed by the intersection of major roads. ${ }^{16}$ As far as possible, the producers, such as growers or fishermen, sold directly to the ultimate consumers, either the town's inhabitants, nearby country people or their servants. Middlemen, from street vendors to larger-scale dealers, were common visitors, though their presence was contested.

London's more complicated market system still adhered to the same principles. Different markets across the City sold different types of food. Some had shops and stalls staffed by citizens, but the street markets were largely given over to country traders. This mixed model, blending wholesale and retail business, was a continual source of argument. ${ }^{17}$ By 1660 , the City of London had 15 official trading spaces,

\footnotetext{
${ }^{14}$ Ian Archer compared two five-year samples of fines for the mid- to late sixteenth century in I.W. Archer, 'Hugh Alley, law enforcement, and market regulation in the later sixteenth century', in I.W. Archer, C. Barron and V. Harding (eds.), Hugh Alley's Caveat: The Markets of London in 1598. Folger Ms V. a. 318 (London, 1988), 15-29, at 23.

${ }^{15}$ Davis, Medieval Market Morality, 176.

${ }^{16}$ Everitt, 'Marketing', 467, 480.

${ }^{17} \mathrm{~V}$. Harding, 'The London food markets', in Archer, Barron and Harding (eds.), Hugh Alley's Caveat, 115, at 5. On the shift towards wholesale markets from the Restoration, see Smith, 'Wholesale and retail markets'.
} 


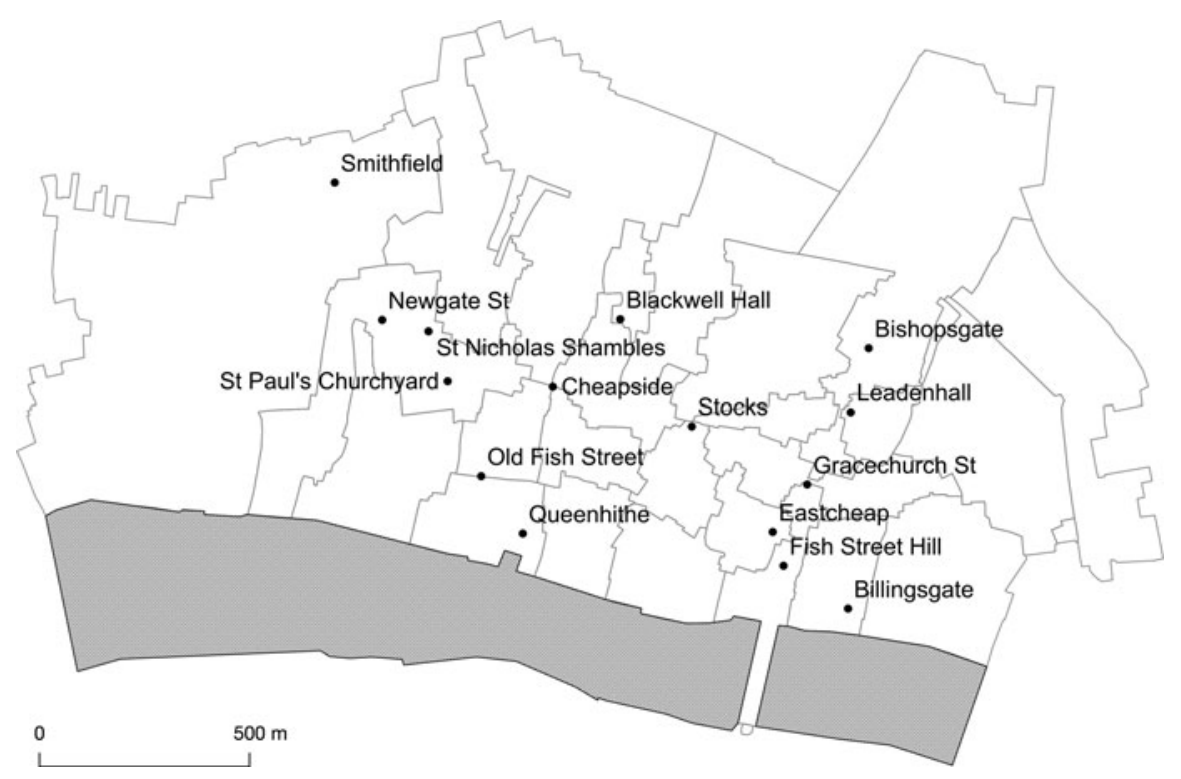

Figure 1. Location of formal markets in the City of London in 1660 Sources: List of markets from Smith, 'Market place', 20. Base map of London wards from William Morgan's Map of London 1682, 'Mapping London' project, Centre for Metropolitan History, Institute of Historical Research, School of Advanced Study, University of London.

with another 6 outside its formal bounds (Figure 1). ${ }^{18}$ Many changed their specialization over this period, but several names, such as Leadenhall and Billingsgate, resonated deep into the nineteenth century. Of the street markets, Cheapside was the most famous. It was a synecdoche for London's food business, evoking a bargain in its name. Cheapside's several sections were dedicated to particular foods, with a white market for veal, pork, bacon and dairy, a poultry market that included rabbits and eggs, and herb wives hawking vegetables, fruit and flowers. The market ran several days a week, from early morning until noon. ${ }^{19}$ Cheapside may have been identified with retail, but its market was not permanent.

The markets were governed by a blend of custom and reactive orders from the City's rulers. It is remarkable how little was formally prescribed. In 1595, London's aldermen published a short pamphlet, The Lawes of the Market. Based on an earlier version from 1562, with almost identical contents, it would be republished in 1620 , 1662 and 1668. The first section has a list of just seven 'lawes': all prices should be set by the mayor; no one should forestall, to buy goods before they came to market; no one should regrate, to buy goods only to sell again; butter should be sold by weight; poulters should not offer stale wares; hucksters should not creep from certain spots; and no unwholesome victuals should be sold. All these offences carried a

\footnotetext{
${ }^{18}$ Smith, 'Market place', 24.

${ }^{19} \mathrm{~V}$. Harding, 'Shops, markets and retailers in London's Cheapside, c. 1500-1700', in B. Blondé, P. Stabel, J. Stobart and I. van Damme (eds.), Buyers and Sellers: Retail Circuits and Practices in Medieval and Early Modern Europe (Turnhout, 2006), 155-70, at 161.
} 
$40 s$ fine, apart from the $3 s 4 d$ for the hucksters, who were perhaps less able to pay. ${ }^{20}$ These rules were not tailored to London. Indeed, they were all medieval principles, confirmed by a 1552 act of Edward VI, which defined and set out punishments for 'regrators, forestallers and ingrossers' ${ }^{21}$ The same was true of the closing section, 'Old Lawes and Customes of this Cittie'. Once more, this contained general principles for social and economic life, such as how only freemen were allowed to set up shop. ${ }^{22}$ The offences in the longer, middle section, 'Statutes of the Streets of this Cittie, against Noysances', are more distinct. Example prohibitions from the 47 points include brewers throwing dregs into the channel and baiting of bulls and bears. ${ }^{23}$ A guide for keeping order in the street was sandwiched between the rules for economic relations. Street behaviour and market management were intimately connected.

More precise market instruction came from the periodic acts and orders of the common council and court of aldermen. The most ambitious of these targeted a range of abuses. An act of February 1600 complained of those who 'regrate fourstall and ingrosse all kind of victualls fruite and all other things'. In response, the council ordered that 'all laws heretofore made' against market crimes were enforced 'in full force \& effort'. In addition, a team of four overseers was appointed. ${ }^{24}$ In the summer of 1631, the common council took action against citizens who flooded the streets, by themselves or with wives, children and servants, and took up standings. These streets were the 'Comon Marketts, unto which the Countrie people onelie have in former times used to resorte, to vende and utter their vittails'. No citizen was to sell outside their shop or house, or they risked a $20 s$ fine. Bells were to be erected in several places, to ring out twice on market days, to signal the start of selling and the moment retailers could join the fray. ${ }^{25}$

Beyond these reactionary interventions, there was no plan for organizing London's food markets. Hugh Alley, one of the overseers appointed in 1600, had a previously drawn up a proposal, his Caveat. In the 1598 plan, Alley complained of typically proscribed activities - forestalling, regrating, engrossing, haggling and hawking. He encouraged Londoners 'not to Rack and Sacke all unto their owne greedie, covetous, purses and paunches', opposing a selfish, individual sin greed - with fair practice in the food trades. ${ }^{26}$ But, importantly, Alley demanded a restatement of old principles, not an overhaul. Foremost was the management of market space. The Caveat contains drawings of several markets, with the aldermen for the respective wards drawn on the facing pages. This suggests that the aldermen, responsible for London's 26 administrative divisions, had responsibility for their local trading areas. Other points are ambiguous. In the sketches, regrators and forestallers have dedicated spots in St Nicholas Shambles and the Stocks. Perhaps these deviants were grudgingly welcomed, or the placements were intended

\footnotetext{
${ }^{20}$ Corporation of London, The Lawes of the Market (London, 1595, ESTC S107723), fols. A3r-A4r.

${ }^{21} 5$ \& 6 Edw. VI, c. 14, in D. Pickering (ed.), Statutes at Large, from the Thirty-Second Year of K. Hen. VIII. to the Seventh Year of K. Edw. VI. (Cambridge, 1763), 377-81.

${ }^{22}$ Corporation of London, Lawes of the Market, fols. B1v-B3r.

${ }^{23}$ Ibid., fols. A4r-B1v.

${ }^{24}$ LMA, Journals, COL/CC/01/01/026, fols. 150v-152r.

${ }^{25}$ LMA, Journals, COL/CC/01/01/036, fols. 332r-333r.

${ }^{26}$ Archer, Barron and Harding (eds.), Hugh Alley's Caveat, 47.
} 
to shame morally dubious traders. Less foggy is Alley's vision of an orderly marketplace. His Cheapside, for example, is an open passage, with no overflowing shops or semi-permanent stalls. Traffic can flow easily. The street market itself is structured around the traditional system, with dedicated places for traders from London, Middlesex, Essex, Kent, Surrey and Hertfordshire to bring their wares.

As suggested by the republication of market laws, the issue of long civic orders and the unrealized plans for reform, the customary way of marketing food to Londoners had to be regularly enforced. But the principle of the open, common market would remain the guiding principle of London's food trade deep into the eighteenth century. ${ }^{27}$

\section{Keeping markets moral}

While the rules of the marketplace were ingrained in urban custom, they still required regular enforcement. Elizabeth and the first Stuart monarchs tried to revive the power of the clerk of the market, who was historically in charge of policing retail trade. ${ }^{28}$ In London, the clerk's powers were vested in the corporation, which delegated authority to ranks of officers. ${ }^{29}$ A constant challenge for historians of early modern London has been untangling the overlapping jurisdictions. The food markets were no different, and it was never entirely clear which of the common council, aldermen, sessions of the peace, livery company courts, annual ward meetings and parish vestries took precedence. ${ }^{30}$ Nor was there an overarching petty court to resolve market offences, such as the court leet in smaller towns. ${ }^{31}$

This makes the chamberlain's book of fines a valuable source for market regulation. The lack of attention it has received may be due to its uncertain role. For example, there is no obvious explanation why the book stops in 1628, with no equivalent book covering earlier or later periods. It is primarily an accounting document, listing the payments received from different officers across London by the chamberlain, the official responsible for the corporation's finances, for each year ending at Michaelmas (29 September). Between 1590 and 1628, there were 1,490 entries, for which the individual amount of the fine is recorded. ${ }^{32}$ My analysis is focused predominantly on the offences related to market trading - regrating, forestalling, hawking, trading in inns, selling at wrong times and food quality concerns - which total 224 fines. There is a further group of offences - buying and selling between foreigners, disruption in the streets and breaking the assize of bread - that were not necessarily tied to the marketplace, but were connected to the culture and practice of early modern marketing. Together, these accounted for an additional 293 fines. The numbers can be misleading. Some of these are group fines, the sum received for a category of offence over a period of time or

\footnotetext{
${ }^{27}$ A.B. Robertson, 'The open market in the City of London in the eighteenth century', East London Papers, 4 (1958), 15-22, at 16.

${ }^{28}$ Everitt, 'Marketing', 578.

${ }^{29}$ Archer, 'Hugh Alley', 22.

${ }^{30}$ M.A. Dorey, 'Unwholesome for man's body? Concerns about food quality and regulation in London c. 1600-c. 1740', University of Western Australia Ph.D. thesis, 2011, 276-7; Smith, 'Market place', 43.

${ }^{31}$ D. Pennington,'Taking it to the streets: hucksters and huckstering in early modern Southampton, circa 1550-1652', Sixteenth Century Journal, 39 (2008), 657-79.

${ }^{32}$ Fines Book, fols. $214 \mathrm{v}-269 \mathrm{v}$.
} 
the City's share of fines issued by the officers of a particular company. Furthermore, the book is not a complete record of market regulation: some offenders may have escaped a fine or been dealt with elsewhere. Still, the source can address some of the difficulties of studying market regulation in London in practice. A few comparable sources exist, such as the presentments of the courts leet in the suburb of Southwark and the account books of the Butchers' company, but they do not necessarily cover an unbroken passage of time or the market system as a whole. ${ }^{33}$ The fines book reveals in unusual detail what market behaviour London's authorities were interested in punishing and how the moralized principles of the marketplace were enforced.

Most of the marketing fines were concerned with governing the space of the market. Because London's street markets only became a sanctioned trading area on certain days and times, officials clamped down on buying and selling in the right place - but at the wrong moment. In 1593, Thomas Barker had to pay up for buying a cow in Smithfield 'before the bell runge'. ${ }^{34}$ Five years later, two fines were taken in for buying sheep before the market bell. ${ }^{35}$ In the period covered, the fines book contains only six entries for trading at incorrect times. All but one of these concerns purchases in Smithfield, a site unusual for being dedicated to livestock. ${ }^{36}$ Other records suggest this particular market was hard to control. In 1605, an act of common council complained about a number of offences there, including trading in stolen animals. In response, the act restated the 'ancient and accustomed' times for buying and selling stock. ${ }^{37}$ Though the precise numbers can be misleading, it seems that fines were not how market times were enforced. Local officials may have resolved infractions informally, or the enforcement of hours was connected to other, more common offences.

Forestalling, proscribed in English law since at least the thirteenth century, concerned the offloading or purchase of goods before they reached the market. ${ }^{38}$ From 1590 onwards, the book lists 20 fines received for forestalling. Of those, 7 concerned small amounts of fruit, eggs, puddings, butter, eggs and poultry, where the money received by the City amounted to $1 s$ (Table 1 ). ${ }^{39}$ The rest involved larger-scale dealers and more severe charges, such as the $10 s$ received for a fine in 1600 against Thomas Atkyns, a fishmonger, for forestalling some cod 'before they came to the market at Billingsgate. ${ }^{40}$ The offence persistently worried the company of Fishmongers, whose court around the same time expressed fears about some of their members riding out to Rye, on the south coast, to strike advantageous

\footnotetext{
${ }^{33}$ J. Boulton, Neighbourhood and Society: A London Suburb in the Seventeenth Century (Cambridge, 1987), 73-5; Dorey, 'Unwholesome', 120-1.

${ }^{34}$ Fines Book, fol. 222v.

${ }^{35}$ Ibid., fol. $229 \mathrm{v}$.

${ }^{36}$ The exemption, a fine for calf skins bought at Leadenhall, does not concern food. See Fines Book, fol. $234 \mathrm{v}$.

${ }^{37}$ LMA, Journals, COL/CC/01/01/027, fols. 320v-321v.

${ }^{38}$ R. Britnell, 'Forstall, forestalling and the statute of forestallers', English Historical Review, 102 (1987), 89-102, at 90-3.

${ }^{39}$ Fines Book, fols. 226r, 227r, 237r, 255r.

${ }^{40}$ Ibid., fol. 233 r.
} 
Table 1. Number of fines received for marketing offences by size of payment received, 1590-1628

\begin{tabular}{lcccccc}
\hline $\begin{array}{l}\text { Marketing } \\
\text { offence }\end{array}$ & $\begin{array}{c}1 s \text { or less } \\
(\mathrm{N})\end{array}$ & $\begin{array}{c}1 s 1 d-2 s \\
(\mathrm{~N})\end{array}$ & $\begin{array}{c}2 s \text { 1d }-5 s \\
(\mathrm{~N})\end{array}$ & $\begin{array}{c}\text { More than } 5 s \\
(\mathrm{~N})\end{array}$ & $\begin{array}{c}\text { Unknown } \\
(\mathrm{N})\end{array}$ & $\begin{array}{c}\text { Total } \\
(\mathrm{N})\end{array}$ \\
\hline Food quality & 1 & 2 & 3 & 0 & 0 & 6 \\
Forestalling & 8 & 4 & 4 & 4 & 0 & 20 \\
Hawking & 18 & 26 & 19 & 7 & 2 & 72 \\
Inn trading & 5 & 7 & 12 & 4 & 0 & 29 \\
Regrating & 39 & 24 & 23 & 2 & 1 & 91 \\
Wrong times & 0 & 2 & 2 & & 0 & 6 \\
\hline
\end{tabular}

Source: Fines Book, fols. 214v-269v.

deals. ${ }^{41}$ Such were the lengths traders went to, as they tried to dodge the competition and oversight of the common market.

Others made illegal bargains in town. A further 29 fines were received for marketing in and around drinking houses, especially inns. The entries are evenly split between those punished for buying and selling, and innholders accused of 'suffering a market to be kept' in their house. ${ }^{42}$ Some of these inns sat towards the City's fringe, such as The Greyhound in Holborn and The White Harte by Cripplegate. ${ }^{43}$ Several ringed Smithfield, such as The Bell, The Greyhound, The Rose and The Saracen's Head without Newgate. ${ }^{44}$ The White Horse in Friday Street and The Three Cups in Bread Street were a short walk from Cheapside. ${ }^{45}$ There were benefits to being close to formal trade, benefiting from the gathering of buyers and sellers and the hubbub of the marketplace, but just out of reach of observers. A little further west was The Saracen's Head on Carter Lane, a chronic blackspot. In 1604 and 1607, its innholder John Dally was fined several shillings. His successor Garrett Kinge was made to pay in 1617. Traders there were charged in $1605,1607,1609$ and $1614 .{ }^{46}$ As Peter Clark has observed, by the early Stuart period, alehouses, taverns and inns were becoming an 'alternative economic centre'. ${ }^{47}$ The recurrence of certain locations may mean an informal system of licensing was at work. ${ }^{48}$ Even so, the prominence of this offence in the fines book, over a span of time, suggests that the aldermen attempted to keep haggling over food within the market bounds.

They were particularly keen to clamp down on hawkers, who walked their wares through the streets. These wandering vendors were the target of a flurry of ordinances in the early seventeenth century. ${ }^{49}$ Fears about women hawking food

\footnotetext{
${ }^{41}$ Guildhall Library, London, Minute Books of the Court of Assistants of the Company of Fishmongers, MS 5570/1, p. 254.

${ }^{42}$ This is the typical wording. For example, see Fines Book, fol. $237 \mathrm{v}$.

${ }^{43}$ Ibid., fols. $239 \mathrm{r}, 253 \mathrm{v}$.

${ }^{44}$ Ibid., fols. 239r, 241r, 255r, 264v.

${ }^{45}$ Ibid., fols. $253 \mathrm{v}, 255 \mathrm{v}$.

${ }^{46}$ Ibid., fols. 237v, 239r, 241r, 241v, 244v, 253r, 253v, 258v.

${ }^{47}$ P. Clark, The English Alehouse: A Social History 1200-1830 (London, 1983), 85, 138. See also M. Hailwood, Alehouses and Good Fellowship in Early Modern England (Woodbridge, 2014), 21.

${ }^{48}$ W.J. King, 'Regulation of alehouses in Stuart Lancashire: an example of discretionary administration of the law', Transactions of the Historical Society of Lancashire and Cheshire, 129 (1979) 31-46, at 37.

${ }^{49}$ For example, see complaints in 1602, in LMA, Journals, COL/CC/01/01/027, fols. 6r-7r.
} 
culminated in a common council act of 1612, which aimed at licensing street vendors. ${ }^{50}$ Hawking was a major source of fines, though 64 of the 72 entries concerned non-edible goods, like baskets, clothes, knives and cushions. These seem to be pedlars or chapmen specializing in petty manufactures. ${ }^{51}$ Hawkers punished this way for selling food tended to sell substantial volumes, such as Robert and John Borebanck, who gave up $8 s$ for wandering with cheeses, to the 'hindrance of shoope keepers'. ${ }^{52}$ At this stage, Bridewell Hospital, the house of correction on the City's western edge, was responsible for the regulation of poor women and men crying fish, oysters and fruit through the streets. ${ }^{53}$ The fines book offers evidence of frequent action against bigger-scale hawkers who posed multiple problems: their itinerancy was a nuisance, these non-freemen competed with citizen retailers and their trade routes took them beyond the common market.

The marketing offence that most exercised City officials was regrating, buying in one market to sell again, sometimes in the same place, sometimes in another. In the fines book, 91 entries are recorded for regrating, on its own 6 per cent of all entries for the years studied. Traders were fined for regrating in a range of markets: Cheapside and Leadenhall are the most commonly mentioned, but there are also payments relating to Bishopsgate Street, Gracechurch Street, Newgate and Southwark. Though Billingsgate is not named, several fines were handed in by the 'underwaterbailiff, one of the riverside officers, for illegal purchases of codlings, eels, flounders, shads, smelts and whitings. ${ }^{54}$ On the whole, the amounts received for the offence were small, ranging from $3 d$ to $8 s 6 d$, but with a median of $1 s 6 d$. Even these minor retailers threatened the integrity of the common market system, by taking advantage of London's multiple trading spaces to make a profit.

We can identify the gender of 66 of those fined for regrating. Of these, 31 were women, a much greater share than for other marketing offences (Table 2). Some appeared repeatedly, such as Anne King, who paid for regrating five geese in 1609 and two years later was charged with buying 32 chickens in Leadenhall, before going to Cheapside and 'selling them againe'. ${ }^{55}$ King, like many of the women, was labelled a 'Comon Huckster' or simply 'huckster'. It is not clear whether this is an occupational title the women might use themselves, or a pejorative term applied to those abusing the markets. Women had a problematic position in the market system. London's demography and economic structure made women conspicuous figures in the marketplaces, buying for households or looking to make money, often outnumbering men, but their presence as traders could be criticized both on the grounds of competition, by disgruntled citizen retailers, and on the grounds of gender, as independent women working across the city. ${ }^{56}$ At heightened moments,

\footnotetext{
${ }^{50}$ LMA, Journals, COL/CC/01/01/029/01, fols. 300r-302r.

${ }^{51}$ M. Spufford, The Great Reclothing of Rural England: Petty Chapmen and their Wares in the Seventeenth Century (London, 1984), 145.

${ }^{52}$ Fines Book, fol. 268r.

${ }^{53} \mathrm{C}$. Taverner, 'Consider the oyster seller: street hawkers and gendered stereotypes in early modern London', History Workshop Journal, 88 (2019), 1-23, at 14-15.

${ }^{54}$ Fines Book, fols. 221v, 222v, 225r, 233v, 234r.

${ }^{55}$ Ibid., fol. 248 r.

${ }^{56}$ On women in the markets, see Hubbard, City Women, 200, 275-6; Reinke-Williams, Women, Work, 103-4, 116; Pennington, Going to Market, 11. On women and urban space, see L. Gowing, “The freedom of
} 
Table 2. Gender of offenders fined for marketing offences in London, 1590-1628

\begin{tabular}{lcccc}
\hline Marketing offence & Men $(\mathrm{N})$ & Women $(\mathrm{N})$ & Unknown $(\mathrm{N})$ & Total (N) \\
\hline Food quality & 5 & 0 & 1 & 6 \\
Forestalling & 10 & 4 & 6 & 20 \\
Hawking & 48 & 13 & 11 & 72 \\
Inn trading & 22 & 3 & 4 & 29 \\
Regrating & 35 & 31 & 1 & 91 \\
Wrong time & 5 & 0 & 25 & 6 \\
\hline
\end{tabular}

Source: Fines Book, fos. 214v-269v.

women traders bore the brunt of public attacks. In the lengthy act of 1630 for reformation of the markets, several of the suspect groups of traders were named specifically as female: oysterwives, herbwives and tripewives. ${ }^{57}$

Restricting who was allowed to buy and sell was a core aspect of market management. In London, where the ideal of producers dealing directly with citizen consumers was complicated in practice, the City governors had to balance the interests of different groups. What appears the simplest rule, as set out in the customs of the City, was that those without the freedom, 'foreigners' or 'foreigns', were not allowed to run a permanent shop, or to trade with another foreigner. The fines book contains 95 entries in this period for a foreigner selling goods to another, though we do not always know whether that business took place in the market. ${ }^{58}$ Another large source of fines, employing a foreigner, was also concerned with distinguishing between free and unfree. As Ian Archer suggested, London's 'matrix of overlapping communities' relied on exclusion, and the most fundamental community was the citizenship. ${ }^{59}$ Even if the majority of adult men were citizens, that still left out great numbers of women, the poor and suburban Londoners, whose activity in the markets could be questioned. ${ }^{60}$ But citizens caused problems too. The commercial potential of feeding England's capital is indicated by the power of the livery companies, each of which supposedly had the sole right to retail in their specialism. This was in tension - if not contradiction - with the system of the common market. $^{61}$ Some companies were first incorporated in the seventeenth century, such as the Gardeners, while others entrenched their monopoly, like the Fishmongers. ${ }^{62}$ Few company members appear in the fines book for offences like forestalling, but company officials handled their members' abuses and, as the century

the streets": women and social space, 1560-1640', in P. Griffiths and M.S.R. Jenner (eds.), Londinopolis: Essays in the Cultural and Social History of Early Modern London (Manchester, 2000), 130-51, at 138.

${ }^{57} \mathrm{LMA}$, Journals, COL/CC/01/01/036, fols. 332r-332v.

${ }^{58}$ Fines Book, fols. 237r, 256v, 263r, 264r, 268r.

${ }^{59}$ I.W. Archer, The Pursuit of Stability: Social Relations in Elizabethan London (Cambridge, 1991), 10.

${ }^{60}$ On the size of the citizenship, see S. Rappaport, Worlds within Worlds: Structures of Life in Sixteenth-Century London (Cambridge, 1989), 28-9.

${ }^{61}$ On the light and dark sides of merchant guilds in economic development, see S. Ogilvie, Institutions and European Trade: Merchant Guilds, 1000-1800 (Cambridge, 2011), 2-3.

${ }^{62}$ McGrath, 'Marketing', p. 48; M. Barnes, Root and Branch: A History of the Worshipful Company of Gardeners of London (London, 1994), 5; J. Colson, 'London's forgotten company? Fishmongers: their trade and their networks in later medieval London', in C.M. Barron and A.F. Sutton (eds.), The Medieval Merchant: Proceedings of the 2012 Harlaxton Symposium (Donington, 2014), 20-40, at 22. 
developed, citizen retailers were accused of buying up shipments and undermining the public markets. ${ }^{63}$

The form of London's markets made policing their bounds difficult. In the capital, as in most towns, the most important marketplaces were not enclosed or covered, sheltered from intruders and unexpected interruptions; instead, those markets were on the street. The concerns of managing urban space more generally mingled with control over where goods were traded. This worried all levels of City government. The annual meeting of residents in Cornhill ward, in 1607 and 1609, heard complaints from residents and the clerk of the market about wheelwrights blocking the streets on Saturdays - the busiest market day. ${ }^{64}$ Alongside the 224 fines for marketing offences, the fines book contains 153 entries for nuisances in the roadways. To take 1604 as a busy example, there were fines for pigs running astray, a brewer keeping hogs, laying dung in the street, letting horses walk unled, emptying vaults and dung carts and pestering the highway with coffins, timber and pipes. ${ }^{65}$ The book records these offences of hygiene and public order together with abuses of the common market, just as they were listed side by side in The Lawes of the Market. The regulation of space and of market trading were part of the same enterprise. This fusion of economic and environmental concerns would have been particularly evident in the first half of the seventeenth century, before London's post-fire renewal. The paving of streets, emergence of new districts and construction of permanent, covered markets transformed how, when and where Londoners bought and sold food, and the demands on market governors. ${ }^{66}$

It is difficult to judge how effectively market rules were enforced. Across this period, the 244 entries for marketing offences are equivalent to about six a year. Although this is an extremely low figure given London's size, this does not represent the entirety of regulation. As has been mentioned, the livery companies employed officers to watch over their markets, while other institutions, such as the wards and Bridewell prison, also contributed. Looking at the patterns of fines over time (Figure 2), it appears that the City pursued offences such as regrating or trading in inns in bursts of prosecution. Most years, a couple of fines were received, but occasionally there were spikes in activity, such as the 37 fines against regrators across 1614 and 1615 . We cannot tie these numbers to specific interventions by City government, like the bylaws targeting regrators and hucksters in 1605 and 1621 or the hawker licensing act of 1612 , but it seems that the latter halves of the 1590 s and 1610 s were busy periods for on-the-ground enforcement. ${ }^{67}$ Whether these flurries of fines are proof of energetic policing or widespread transgression, they suggest that market regulation was characterized by irregular, exemplary punishment, rather than constant intervention. The fines themselves were not especially onerous: marketing offences accounted for 15 per cent of all entries in the fines book, but only 5 per cent of the revenue; the size of most fines was tied to the

\footnotetext{
${ }^{63}$ On the Fishmongers' abuses, see C. Taverner, 'Selling food in the streets of London, c. 1600-1750', Birkbeck, University of London Ph.D. thesis, 2019, ch. 2.

${ }^{64}$ LMA, Cornhill Wardmote Books, CLC/W/HF/001/MS04069/001, fols. 106v, 113v.

${ }^{65}$ Fines Book, fols. $236 \mathrm{v}-237 \mathrm{v}$.

${ }^{66}$ Smith, 'Market place', 173.

${ }^{67} \mathrm{LMA}$, Repertories of the Court of Aldermen (Repertories), COL/CA/01/01/030, fol. 10r; COL/CA/01/ 01/039, fol. 240v; LMA, Journals, COL/CC/01/01/038, fol. 142r.
} 
ิิธิ์

Fines collected for marketing offences in London, 1590-1628

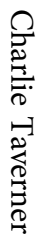

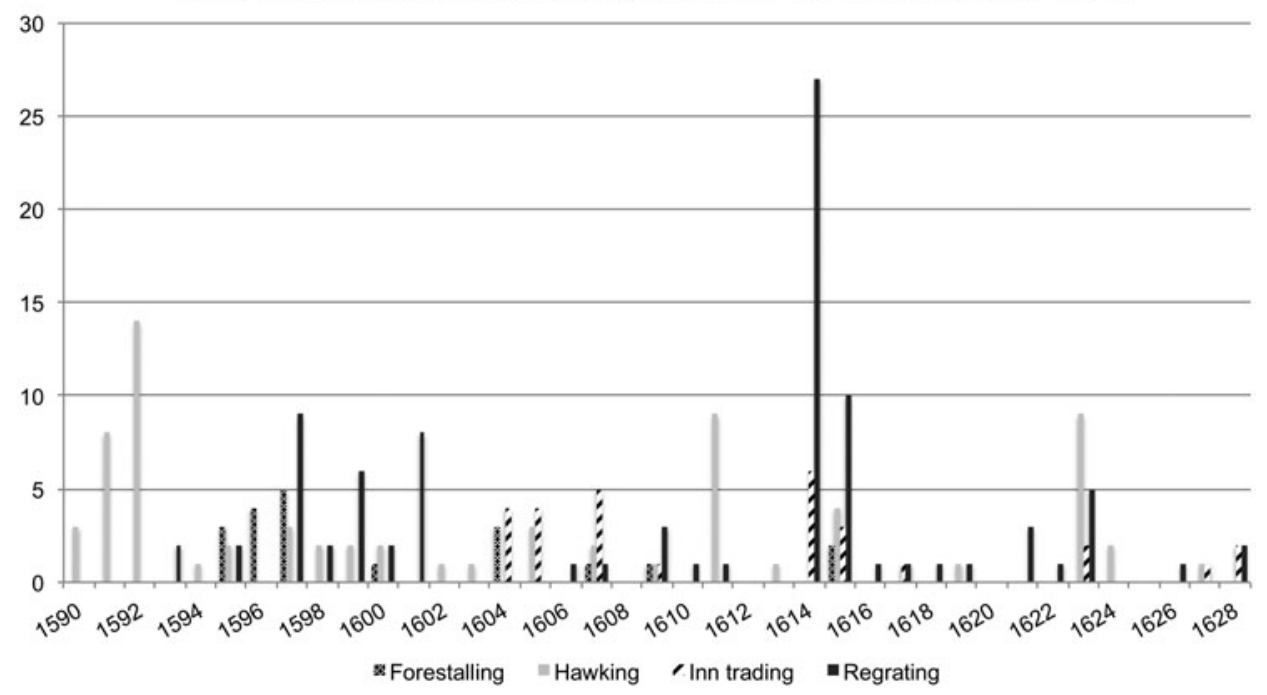

Figure 2. Number of fines entered for forestalling, hawking, trading in inns and regrating, 1590-1628 Source: Fines Book, fols. 214v-269v. 
value of the traded goods. ${ }^{68}$ To make a stronger statement, the aldermen could use spectacle. In August 1607, Robert Dowle, a gardener, was found to have 'verye decciptfully sold' cabbage seeds, which had turned out bad. Dowle was to be set in the stocks in Cheapside for two hours in the morning, when the market was in full flight. ${ }^{69}$ Public punishment was one of Cheapside's several, historic roles. ${ }^{70}$ Though the bustling street market was hard to control, the mayor and aldermen could use this public space to declare themselves as the arbiters of city space and protectors of the moralized marketplace.

\section{Marketing for the common good}

Underpinning this market regulation was a set of beliefs about price. In London at this time, food prices were not fixed; rates were set by the supply of and demand for the goods that arrived in the marketplace. A qualified exception was the assize. From the thirteenth century, the mechanism had governed the weight, measures, quality and price of bread, wine and ale. ${ }^{71}$ Local governors announced schedules for different weights and volumes, linking the raw material's price to the final value. This let bakers and brewers earn a reasonable, yet not excessive profit, while limiting the opportunities for profiteers. Despite London's early commercialization, the assize was still fully functioning in the first 40 years of the seventeenth century. ${ }^{72}$ Alongside the other features of market regulation, charges against deviant bakers were entered in the fines book, in particularly high numbers in the dearth-struck 1590s.

For most goods, the market was left alone to determine what food was worth. In normal times, what mattered was how much arrived to market and what buyers required. Price control was 'comparatively rare' in the seventeenth century, with an unusual schedule published by the Poulterers in $16344^{73}$ Assize aside, the fines book contains no entries for charging too much or paying too little for food in the markets. The tools of regulation were concerned with keeping trade to defined marketplaces, and stopping abuses and deception within that regulated space. Part of this meant keeping a check on quality, as well as weights and measures. In August 1615, the common council heard how 'more deceipt is of late used by buying and selling by false waights Beames Balances and Seales than ever in any time heretofore hath bene practized'. These abuses had caused the 'greate defraudinge' of the king's subjects and the 'highe displeasure of Almightie God'. ${ }^{4}$ To manipulate the common market, the councilmen suggested, was not just economic fraud; it was an aberration offensive to the Lord.

\footnotetext{
${ }^{68}$ Each entry records only the corporation's share of the goods forfeit for being bought or sold illegally, after officers were paid for their costs.

${ }^{69} \mathrm{LMA}$, Repertories, COL/CA/01/01/031, fol. 77r.

${ }^{70} \mathrm{~V}$. Harding, 'Cheapside: commerce and commemoration', Huntington Library Quarterly, 71 (2008), $77-96$, at $90-4$.

${ }^{71}$ Davis, Medieval Market Morality, 231-3; Davis, 'Baking'.

${ }^{72}$ D.J.S. Carmichael, 'Feeding and supporting the poor of London in the early seventeenth century', University of London Ph.D. thesis, 2014, 110-11.

${ }^{73}$ P.E. Jones, The Worshipful Company of Poulterers of the City of London: A Short History (Oxford, 1981), 135; McGrath, 'Marketing', 34.

${ }^{74}$ LMA, Journals, COL/CC/01/01/030, fol. 377r.
} 
The aim of the market rules was to let prices reach a natural level - the just price. Belief in that mechanism goes back to medieval philosophy. Romanist and canonist scholars, writing in the twelfth and thirteenth centuries, concluded that the just price was simply the current price, determined by the supply of goods and the demand of buyers in a particular marketplace. For this equilibrium to be reached, the marketplace had to be free of monopolies and deception. ${ }^{75}$ This abstract doctrine, debated by lawyers and theologians, became embedded in the laws of medieval English towns. ${ }^{76}$ Wanting to secure food as cheaply as possible, urban rulers encouraged competition by drawing country producers to market, while restricting the activities of middlemen, hawkers and brokers, who bought up supplies to sell again and so disrupted the price-setting process. With all food exchanged in the competitive space of the open, public market, the prices fetched would be 'just'. ${ }^{77}$ This logic lay beneath the medieval and early modern understanding of how the space of the market was regulated. The self-interest of traders was harnessed in the London's regulated marketplaces, where it worked for the common good.

The notion of commonality runs through the market regulations in London. A common council act of 1600 complained about the damage done to the 'common markets' of the City. A preamble to a 1602 act described a threat to an old system, in which goods were supposed to arrive at the 'open and publique market'. As we heard earlier, in a 1631 act, the common council described regulations for the 'streets and places appointed for the Comon Marketts, unto which the Countrie people onelie have in former times used to resorte. ${ }^{78}$ Under the traditional system, food was supposed to arrive at the central marketplace, where prices would be set by fair competition, in full display. The language used to reinforce that principle centred on commonwealth and custom.

Those notions did not necessarily place the market authorities on the side of all Londoners. For Thompson, custom was the 'rhetoric of legitimation' for a number of rights and practices, including the moral economy of the grain rioters. ${ }^{79}$ But custom could be drawn on by political theorists and social elites, as well as by plebeians. ${ }^{80}$ Senses of commonwealth were just as ripe for appropriation. While David Rollison has suggested commonwealths derived authority from representing all inhabitants rather than just wealthy sorts, lords or civic institutions, Phil Withington's seventeenth-century 'city commonwealths' were composed of the

\footnotetext{
${ }^{75}$ J. Baldwin, 'Medieval theories of the just price: romanists, canonists and theologians in the twelfth and thirteenth centuries', Transactions of the American Philosophical Society, n.s. 49 (1959), 1-92, at 29, 54, 71-3.

${ }^{76} \mathrm{R}$. Britnell, 'Price-setting in English borough markets, 1349-1500', Canadian Journal of History, 31 (1996), 1-15, at 15 .

${ }^{77}$ R. de Roover, 'The concept of the just price: theory and economic policy', Journal of Economic History, 18 (1958), 418-34, at 424, 428-9.

${ }^{78}$ LMA, Journals, COL/CC/01/01/026, fols. 150v-152r, COL/CC/01/01/027, fols. 6r-7r, COL/CC/01/01/ 036, fols. 332r-333r.

${ }^{79}$ Thompson, Customs in Common, 6.

${ }^{80} \mathrm{~A}$. Wood, The Memory of the People: Custom and Popular Senses of the Past in Early Modern England (Cambridge, 2013), 112-19; J.P. Bowen and A.T. Brown, 'Introduction: custom and commercialisation in English rural society', in Bowen and Brown (eds.), Custom and Commercialisation, 1-19, at 17-18.
} 
enfranchised freemen of the city. ${ }^{81}$ When regulating the markets, the aldermen, guilds and their officers used these terms to justify their actions, but the meaning of this language was flexible. Suspect traders such as hawkers or women regrators were excluded from the community that the customary, common markets were intended to benefit.

Throughout the half-century on which this article focuses, several factors made controlling London's markets more challenging. Archer argued that Hugh Alley's 1598 plan emerged from the swirling worries of the last decade of the sixteenth century, about rising prices, dearth, the old market machinery no longer functioning and popular unrest. ${ }^{82}$ The cost of living in London leapt by up to a quarter compared to the previous 10 years, and sharp food price inflation continued into the following century. ${ }^{83}$ This coincided with a crackdown on entertainments, prostitution and drinking, linked to the perception that the city was changing in unsettling ways. ${ }^{84}$ For a long time, London had been creeping away from the customary marketing system. With the tentacles of its food supply reaching further into the regions, London relied on commercial middlemen. ${ }^{85}$ The mixed use of streets became a problem too. Cheapside, the most important street market, was also home to some of the capital's most desirable shops and houses, the inhabitants of which increasingly detested the disruption of food traders outside their doors. ${ }^{86}$ Considering these trends, historians have argued that the corporation's regulation of food marketing was 'mercurial' in the first half of the seventeenth century. Management became stricter only after 1666, when the market structure was properly overhauled, reflecting the growth of the suburbs beyond the walls. ${ }^{87}$

The fact that the aldermen contained these pressures, despite the appearance of minimal enforcement, suggests that the system of market regulation was fairly successful. There were food riots in 1595, led by apprentices and fuelled by the decade's surging prices. ${ }^{88}$ But, based on analysis of the orders and acts passed by City rulers and the revenues recorded in the fines book, it seems that market management was light-touch, rather than sporadic. Undoubtedly, more enforcement went on than an accounting document, such as the fines book, records. Historians of crime have shown how, in the same period, the increasing use of summary justice brought about swift, informal resolutions, though such judgements are badly documented. ${ }^{89}$ Similarly, in the markets, officers likely dealt with some infractions without recourse to higher authority. The economic regulation captured in the archive

\footnotetext{
${ }^{81} \mathrm{P}$. Withington, The Politics of Commonwealth: Citizens and Freemen in Early Modern England (Cambridge, 2005), 266-7; D. Rollison, Commune, Country and Commonwealth: The People of Cirencester, 1117-1643 (Woodbridge, 2011), 2.

${ }^{82}$ Archer, 'Hugh Alley', 24-5.

${ }^{83} \mathrm{~J}$. Boulton, 'Food prices and the standard of living in London in the "century of revolution", 15801700', Economic History Review, 53 (2000), 455-92, at 468-9.

${ }^{84}$ Archer, Pursuit of Stability, 243-54; P. Griffiths, Lost Londons: Change, Crime, and Control in the Capital City, 1550-1660 (Cambridge, 2008), xiii-xiv.

${ }^{85}$ Fisher, 'Development', 50, 58.

${ }^{86}$ Harding, 'Cheapside', 80.

${ }^{87}$ Smith, 'Market place', 154-5.

${ }^{88}$ Archer, Pursuit of Stability, 1-2, 6-7.

${ }^{89}$ For example, see F. Dabhoiwala, 'Summary justice in early modern London', English Historical Review, 121 (2006), 796-822.
} 
may represent the tip of the submerged bulk of informal market management. But it may also suggest that the resilience of this marketing system was connected to its grounding in broad, cultural values. In the common markets of London, buyers and sellers were aware of the roles and expectations required of them, when they came to strike a deal.

\section{Conclusion}

This article has made the case that everyday food selling in urban markets was infused with moralized values. In this way, it builds on the conclusions of Muldrew, Davis and others, who have found that a concern for equitability and fairness was retained throughout a period of commercialization and social upheaval, even outside flashes of protest such as grain riots. These moralized values had relevance to urban residents of fast-growing London, as they did to the labourers and artisans of rural England. The experience of England's capital was exceptional and should not be automatically taken as typical of the country at large. That only makes the focus of London's rulers on maintenance of the common market more striking. The aldermen achieved this by punishing traders who threatened the integrity of the market as a defined space within the city, such as regrators and forestallers. The principle of the just price relied on all transactions taking place in the markets, where the individual interests of both buyers and sellers were harnessed for the public good. London's scale and incessant hunger put its already complex, commercialized system under stress in the first half of the seventeenth century, and the reorganization that accelerated in the Restoration was sorely needed. But the moralized framework of market rules helped London to feed itself, while maintaining a sense of order in the streets and open spaces of Cheapside, Leadenhall and Billingsgate. The evidence of London's food markets shows the difficult transition away from Thompson's 'old moral economy of provision' extended over several centuries. Expanding towns and cities, even England's sprawling capital, were an important battleground. ${ }^{90}$

\footnotetext{
${ }^{90}$ Thompson, 'Moral economy', 132.
}

Cite this article: Taverner C (2021). Moral marketplaces: regulating the food markets of late Elizabethan and early Stuart London. Urban History 48, 608-624. https://doi.org/10.1017/S0963926820000450 